\title{
Development of integrated multi-trophic aquaculture (IMTA) for tropical brackishwater species in Sindhudurg District, Maharashtra, west coast of India
}

\author{
C. P. BALASUBRAMANIAN ${ }^{1}$, SHAILESH S. MHASKAR ${ }^{1}$, KRISHNA SUKUMARAN ${ }^{1}$, \\ A. PANIGRAHI ${ }^{1}$, KUMARAGURU VASAGAM ${ }^{1}$, P. KUMARARAJA ${ }^{1}$, DURGA THIGALE ${ }^{2}$, \\ ROHIT SAWANT $^{2}$, K. K VIJAYAN ${ }^{1}$ AND N. VASUDEVAN ${ }^{3}$ \\ ${ }^{1}$ ICAR-Central Institute of Brackishwater Aquaculture, 75 Santhome High Road, R. A. Puram, Chennai- 600028 \\ Tamil Nadu, India \\ ${ }^{2}$ Mangrove Cell, Malvan, Tal-Malvan, Sindhudurg - 416 606, Maharashtra, India \\ ${ }^{3}$ Mangrove Cell, Bandra East, Mumbai - 400 051, Maharashtra, India \\ e-mail: cpbalasubramanian@yahoo.com
}

\section{ABSTRACT}

\begin{abstract}
Integrated multi-trophic aquaculture (IMTA), farming of species from different trophic levels and with complimentary ecosystem function, is regarded as a suitable approach to develop a sustainable aquaculture system. In order to establish an IMTA system, a study was carried out in Sindhudurg District, Maharashtra, India for selected tropical brackish-water species. Two equal sized pens $\left(250 \mathrm{~m}^{2}\right)$ were constructed for IMTA and control respectively in each land based system and open water cages were set in the estuary. Different combinations of fed species (Chanos chanos, Etroplus suratensis, Mugil cephalus, Penaeus indicus) and an extractive crop (Crassostrea madrasensis) were stocked in IMTA experimental system whereas monoculture of $P$. indicus served as control. Water quality characteristics were found to be within the admissible limits. Soil organic carbon was found to be lesser in the IMTA system compared to control. The productivity of IMTA system was higher than control: $3250 \mathrm{~kg} \mathrm{~h}^{-1}$ vs $2000 \mathrm{~kg} \mathrm{ha}^{-1}$. Further, income and benefit-cost ratio was found to be higher in IMTA pens. The present study concludes that IMTA is a possible option for system diversification as well as species diversification without compromising economic profitability of culture.
\end{abstract}

Keywords: Brackishwater aquaculture, Extractive crops, Fed species, Integrated multi-trophic aquaculture

\section{Introduction}

In India, modern aquaculture particularly shrimp culture, has become a major export oriented seafood producing sector that is contributing to the tune of $\sim$ US\$ 5 billion to the country (MPEDA, 2016). Despite the undoubted growth and sophistication in the shrimp farming industry, there is an increasing concern on the prospects for its sustainability (Naylor et al., 2000). In aquaculture, environmental neutral or benign practices alone do not make a system sustainable, but it should also be economically profitable (Barrington et al., 2010). Further, in aquaculture both sustainability and profitability are interdependent on virtually same factors (Neori and Nobne, 2012). For example, in shrimp aquaculture feed represents about $60 \%$ of operating cost and the major ingredient of formulated feeds has been fish meal derived from the smaller pelagic fisheries (Rana et al., 2009). Further, it was reported that more than $50 \%$ of formulated feed remain unused (Primavera, 1997) and thus the profitability of monoculture and sustainability are directly linked. Brackishwater aquaculture in India is nearly synonymous with monoculture of shrimp and this system is more vulnerable to volatility both in production and prices. Further, the more a system is managed to take maximum yield, it would become less resilient and more vulnerable to abiotic and biotic shock. Therefore, diversification of systems and species used for culture are considered to be the key elements to strengthen the resilience to food production system and its sustainability.

Integrated multi-trophic aquaculture (IMTA), is the farming of species from different trophic levels with complementary ecosystem function in proximity (Chopin et al., 2008). In this farming practice, uneaten feed, nutrients, wastes and energy of one species or crop are recaptured and utilised as fertiliser, feed and energy for other co-cultured species or crops. When diet introduced to a fed species (for e.g., fish or shrimp), it will be partially egested as feces or fully excreted as soluble nutrient that could be captured by co-cultured species (organic extractive: bivalves; inorganic extractive: seaweed) (Reid, 2011). Thus, efficiency of the whole system improves. A distant prototype of IMTA existed in many Asian 
countries as polyculture of different species, often species from same trophic level. The importance of IMTA as a management option for sustainable ecosystem functions along with economic benefits has been recognised recently.

Brackishwater aquaculture has not developed in many states on the west coast (Kerala, Karnataka, Goa, Maharashtra and Gujarat) as in the case of east coast of India, eventhough aquaculture potential in these states is high. Maharashtra has $\sim 80000$ ha of brackishwater area of which $\sim 12445$ ha are suitable for aquaculture with an annual production of only $\sim 7000 \mathrm{t}$ of shrimp (Sadafule et al., 2013; MPEDA, 2016). This paper summarises the initial results of establishing IMTA system in Sindhudurg District of Maharashtra, one of the first initiative in this direction on the west coast. Both land based and open-water IMTA systems with shrimp and finfish as fed species and backwater oyster as non-fed species were attempted.

\section{Materials and methods}

Sindhudurg is the southernmost coastal district of Maharashtra with a coastal length of $121 \mathrm{~km}$. Two land based aquaculture farms (Farm A: 15'51'25.4”N; 73³7'39.3”E, Farm B: 1556'43.2”N; $\left.73^{\circ} 33^{\prime} 15.6^{\prime \prime} \mathrm{E}\right)$ and an open water cage culture system (Site 1: $16^{\circ} 17^{\prime} 11.6^{\prime \prime} \mathrm{N} ; 7^{\circ} 24^{\prime} 15.4$ 'E, Fig. 1) were used for the study. Both the land based farms are under the ownership of private farmers and operated individually. For the establishment of land based IMTA, two ponds of

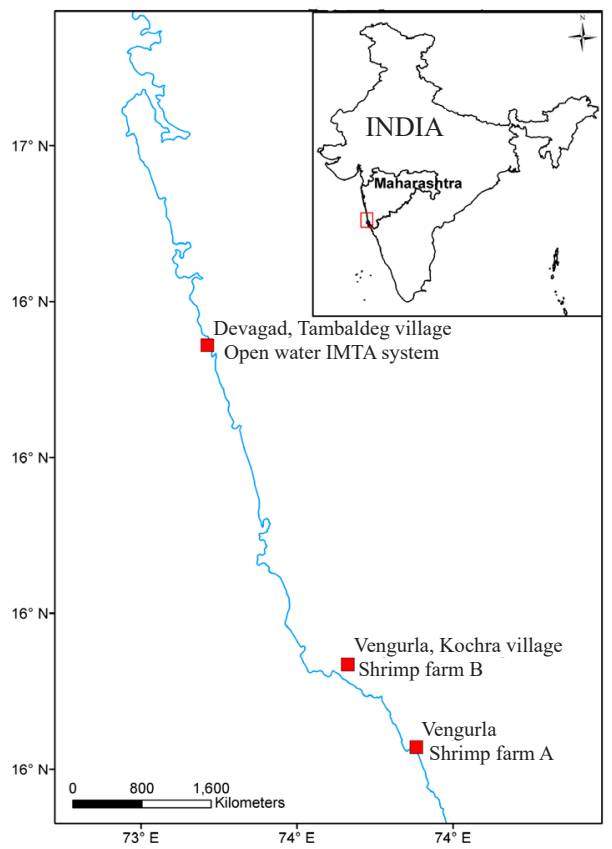

Fig. 1. Map of Sindhudurg District of Maharashtra (India) showing the IMTA pilot farm sites
$10000 \mathrm{~m}^{2}$ (Farm A) and $8000 \mathrm{~m}^{2}$ (Farm B) were used. Owing to the non-availability of sufficient ponds, two pens of $250 \mathrm{~m}^{2}$ with mesh size of $5 \mathrm{~mm}$ were constructed (for IMTA and control) in each pond (Fig. 2 and 3). Ponds were dried and exposed to sunlight before beginning of the experiments. Lime was applied to the pond bottom at $500 \mathrm{~kg} \mathrm{ha}^{-1}$. After one week of lime application, ponds were filled with brackishwater from the nearby creek and fertilisation was carried out using fermented rice bran $(50 \mathrm{~kg})$, jaggery $(5 \mathrm{~kg})$ and yeast $(0.5 \mathrm{~kg})$. Both the experimental pens were stocked with two different stocking densities (Farm A: Chanos chanos: 14; Etroplus suratensis: 2; Mugil cephalus: 0.5 and Penaeus indicus: 1 no. $\mathrm{m}^{-2}$; Crassostrea madrasensis: 0.5 no. $\mathrm{m}^{-2}$; Farm B: C. chanos:14; E. suratensis: 1.5 ; M. cephalus: 0.5 and P. indicus: 1 no. $\mathrm{m}^{-2}$ and C. madrasensis: 0.5 no. $\mathrm{m}^{-2}$ ). As the size of the shrimps was smaller than mesh size of the pen, they were initially grown in pond hapas for $\sim 45$ days, and transferred subsequently to the pens. Low cost formulated pellet feed with $30 \%$ protein developed by ICAR-Central Institute of Brackishwater Aquaculture (ICAR-CIBA) was provided as supplementary feed at 2-5\% body weight (Biswas et al., 2012). Feed quantity

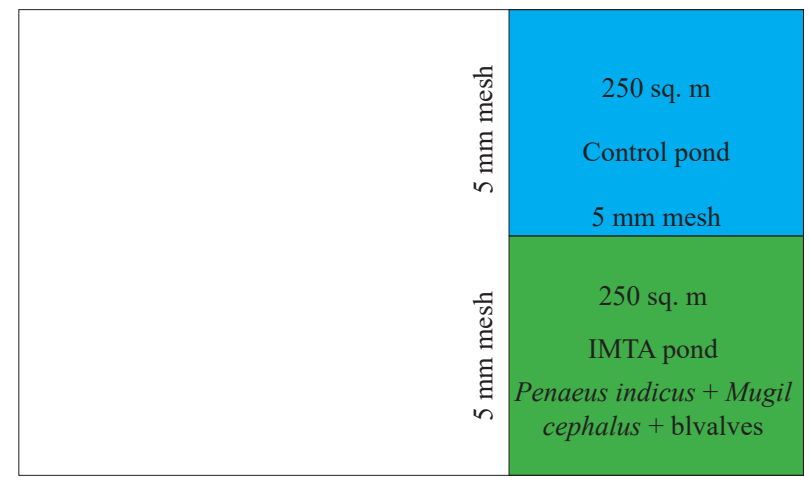

Fig. 2. Scheme of experimental and control farms constructed in the land based IMTA system

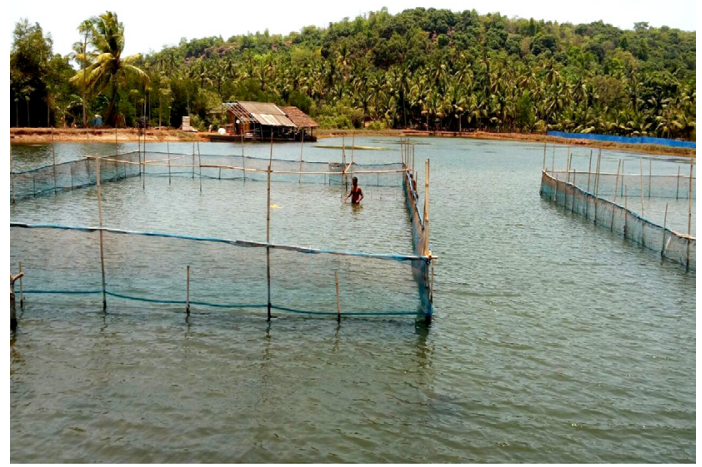

Fig. 3. Land based IMTA system 
was adjusted at 15 days interval based on the body weight of shrimp and finfish.

For the determination of growth rate and feed adjustments, samples were collected periodically (every 2-4 weeks). The length and weight from random samples of fish and shrimp were measured using sliding caliper and digital weighing balance respectively. Every fortnight, water samples were collected from pond as well as source water and analysed for important water characteristics such as salinity, $\mathrm{pH}$, dissolved oxygen (DO), ammonianitrogen $\left(\mathrm{NH}_{3}-\mathrm{N}\right)$, nitrite-nitrogen $\left(\mathrm{NO}_{2}-\mathrm{N}\right)$, nitratenitrogen $\left(\mathrm{NO}_{3}-\mathrm{N}\right)$, phosphate phosphorous $\left(\mathrm{PO}_{3} \mathrm{P}\right)$ and total alkalinity. Samples were analysed using commercial water quality test kits (Biosol, AA Biotech Pvt. Ltd.). Salinity was measured using hand-held refractometer (ATAGO, Japan).

After 110 days of stocking, experimental systems were partially harvested using drag net; fish and shrimp performance were evaluated in terms of average body weight, daily weight gain (= mean final weight - mean initial weight/rearing duration in days) and specific growth rate $[=\log$ (final weight)-log (initial weight)/time x 100 where $\log$ is natural logarithm]. As farms could not be drained completely, survival and production was determined from the number of animals harvested and their mean body weight.

The net income and benefit cost ratio (BCR), were calculated employing the following equations:

$$
\begin{aligned}
& \text { Net income } \\
& \text { Benefit cost ratio }(\mathrm{BCR})=\text { Total income }- \text { total expenditure } \\
& \text { income/Total expenditure }
\end{aligned}
$$

\section{Results}

Mean salinity was highest at site 1 , where open cage IMTA was established (35.08 \pm 0.33$)$ with a minimum of $30 \%$. Salinity of the land based IMTA sites were similar with a mean of $31.68 \pm 1.83$ and $31.79 \pm 3.2$ at farm A and farm B respectively (Fig. 4). However, minimum salinity of these farms was as low as $10 \mathrm{ppt}$ in June. Water quality characteristics such as ammonia nitrogen, $\mathrm{NH}_{3} \mathrm{~N}$ and nitrite nitrogen $\mathrm{NO}_{2} \mathrm{~N}$ were below $<0.25 \mathrm{ppm}$ in all the experimental sites during the culture period. In general, water quality characteristics of all experimental sites were within the acceptable limit for brackishwater shrimp and finfishes. However, salinity during the monsoon season was found to be at lower side for oyster C. madrasensis. The soil organic carbon after harvest was found to be significantly higher in the control site than the IMTA sites (Fig. 5).

Details of final average body weight, daily weight gain and specific growth rate and production in the IMTA

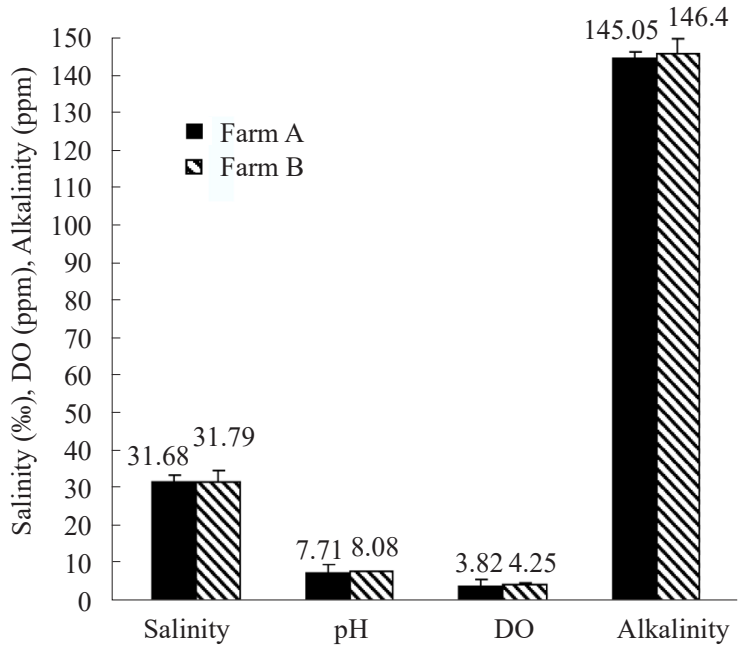

Fig. 4. Water quality characteristics of farm A and B

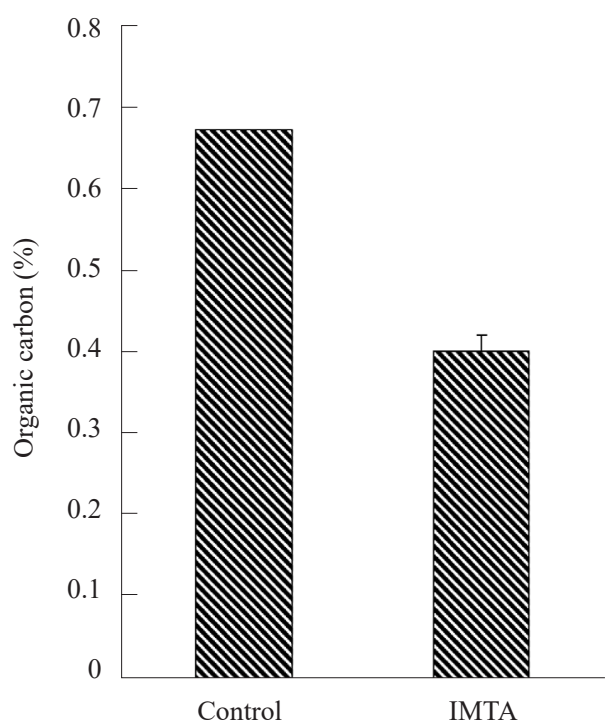

Fig. 5. Soil organic carbon levels in control and IMTA sites after the harvest

pond based culture system are given in Table 1 . The meat weight at day 45 of rearing in hapa was taken as Initial weight of shrimp. As there was no difference in growth rate and yield between farm $\mathrm{A}$ and $\mathrm{B}$, the data were clubbed together for analysis. The growth of shrimp in the IMTA and control pond was found to be similar. Although higher growth was observed in the IMTA pen than control pen, difference was not statistically significant. Among finfishes, M. cephalus showed higher growth followed by E. suratensis. Gross production and productivity of IMTA pens were higher than the shrimp monoculture pen. The productivity of IMTA pen was $3250 \mathrm{~kg} \mathrm{ha}^{-1}$ compared to $2000 \mathrm{~kg} \mathrm{ha}^{-1}$ of monoculture shrimp pen. The edible oyster C. madrasensis grew from spat size to $52.1 \mathrm{~mm}$ during the culture period and the production was $100 \mathrm{~kg}$. 
Table 1 . Final average body weight $(\mathrm{g})$, daily weight gain, specific growth rate $(\%)$ and production $\left(\mathrm{kg} \mathrm{ha}^{-1}\right)$ in IMTA pond based culture system

\begin{tabular}{llllll}
\hline Species & $\begin{array}{l}\text { Final body weight } \\
\text { Mean } \pm \text { SE }(\mathrm{g})\end{array}$ & $\begin{array}{l}\text { Daily weight } \\
\text { gain }(\mathrm{g})\end{array}$ & $\begin{array}{l}\text { Specific growth } \\
\text { rate }(\%)\end{array}$ & $\begin{array}{l}\text { Survival } \\
(\%)\end{array}$ & $\begin{array}{l}\text { Production } \\
\left(\mathrm{kg} \mathrm{ha}^{-1}\right)\end{array}$ \\
\hline Penaeus indicus & $14.20 \pm 2.80$ & 0.14 & 1.77 & 57.6 & 216 \\
Etroplus suratensis & $47.72 \pm 2.59$ & 0.42 & 2.44 & 80.0 & 800 \\
Chanos chanos & $27.64 \pm 1.59$ & 0.24 & 2.63 & 71.0 & 2800 \\
Mugil cephalus & $49.96 \pm 6.28$ & 0.47 & 2.93 & 80.0 & 200 \\
\hline
\end{tabular}

The economic analysis performed to evaluate the net income and benefit-cost ratio between IMTA ponds and shrimp monoculture ponds revealed both net income and BCR to be higher in IMTA ponds (Table 2).

\section{Discussion}

This study reports the results of the experiments conducted during the initial establishment of land-based IMTA system in Sindhudurg District of Maharashtra, India. This is the first of its kind for the development of IMTA for brackishwater aquaculture in India. Further, results of the present study indicates possible development of IMTA as a low-intensive aquaculture practice, contrary to most IMTA developed in the west, where it is based on intensive culture systems (Alexander et al., 2016). Accumulation of nutrients has been one of the important issues of intensive aquaculture (Neori et al., 2000) and that has given a negative public image to aquaculture (Naylor et al., 2000). Consequently, the objectives of most IMTA systems developed in the west were to reduce the nutrient accumulation and feed wastage (Abreu et al., 2009; Granda et al., 2015). In Sindhudrug District, more than $50 \%$ of the registered shrimp farms are disused (http://www.caa.gov. in/farms.html) owing to the frequent disease outbreak and subsequent crop failures and farmers are unable to invest further in shrimp farming. Hence, many farmers left the

Table 2. Comparison of economic returns of land based IMTA ponds with shrimp monoculture ponds (values are average of two farms adjusted for 6 months)

\begin{tabular}{|c|c|c|c|c|c|}
\hline Items & Amount $\left(₹\right.$ ha $\left.^{-1}\right)$ & Price rate $(₹)$ & IMTA (₹) & Amount (₹) & Monoculture shrimp (₹) \\
\hline \multicolumn{6}{|l|}{ Operational cost } \\
\hline \multicolumn{6}{|l|}{ Seed } \\
\hline Penaeus indicus & 20000 & 0.2 & 4000 & 60000 & 12000 \\
\hline Chanos chanos & 20000 & 2 & 40000 & & \\
\hline Etroplus suratensis & 10000 & 1 & 10000 & & \\
\hline Mugil cephalus & 10000 & 2 & 20000 & & \\
\hline Crassostrea madrasensis & 5000 & 0.2 & 1000 & & \\
\hline $\begin{array}{l}\text { Bleaching powder }(\mathrm{kg}) ; 15 \mathrm{ppm} \text {, } \\
1 \mathrm{~m} \text { depth }\end{array}$ & 200 & 25 & 5000 & 200 & 5000 \\
\hline Fertilizers & 1000 & 2 & 2000 & 1000 & 2000 \\
\hline Labour man days & 200 & 270 & 54000 & 200 & 54000 \\
\hline Feed & 9000 & 30 & 270000 & 9000 & 270000 \\
\hline Total operational cost & & & 406000 & & 343000 \\
\hline $\begin{array}{l}\text { Interest in operation cost for } \\
6 \text { months }\end{array}$ & $12 \%$ & & 24360 & $12 \%$ & 20580 \\
\hline Total cost & & & 430360 & & 363580 \\
\hline \multicolumn{6}{|l|}{ Total revenue } \\
\hline Penaeus indicus & 250 & 250 & 62500 & 2000 & 500000 \\
\hline Chanos chanos & 2000 & 200 & 400000 & & \\
\hline Etroplus suratensis & 800 & 150 & 120000 & & \\
\hline Mugil cephalus & 200 & 200 & 40000 & & \\
\hline Crassostrea madrasensis & & & 10000 & & \\
\hline Total profit & & & 632500 & & 500000 \\
\hline Profit per kg & & & 194.6 & & 250 \\
\hline Benefit cost ratio (BCR) & & & 1.5 & & 1.4 \\
\hline
\end{tabular}


sector and therefore, system diversification is the urgent need for those who are involved in shrimp farming in the region. In this context, development of IMTA can certainly play an important role in providing a sustainable as well as affordable option which can attract the farmers to brackishwater farming.

The total productivity of IMTA system obtained during the present study was found to be higher than the finfish-shrimp polyculture system of West Bengal (Biswas et al., 2012). During the present study, the highest daily growth rate was observed in $M$. cephalus $\left(0.47 \mathrm{~g} \mathrm{day}^{-1}\right)$. Biswas et al. (2012) have also reported higher growth rate in $M$. cephalus reared in brackishwater ponds of Kakdweep (West Bengal, India) and they concluded that the higher growth rate of $M$. cephalus is because of its inherent higher growth potential. Further, Luther (1967) reported that all the species of mullet grow faster in culture environment than in the natural environment. Among the finfishes, milkfish had a lower growth rate $\left(0.24 \mathrm{~g} \mathrm{day}^{-1}\right)$ in the present IMTA system contrary to earlier reports. Eldani and Primavera (1981) reported a daily growth rate of 1.28 to $1.65 \mathrm{~g} \mathrm{day}^{-1}$ for milkfish in polyculture pond with tiger shrimp. In brackishwater ponds of Kakdweep, Biswas et al. (2012) obtained a growth rate of $0.7 \mathrm{~g} \mathrm{day}^{-1}$ for milkfish in their polyculture trial along with tiger shrimp. The lower growth rate obtained during the present study may be due to the comparatively higher stocking density, which needs to be sized down in the future trials. The daily growth of $E$. suratensis recorded was found to be lower than the earlier report of $120-130 \mathrm{~g}$ in 6-8 months by Padmakumar et al. (2012). The lower growth rate reported here could be attributed to the high saline condition that prevailed during the culture period. The daily growth rate of $P$. indicus in the IMTA pond was $0.14 \mathrm{~g}^{\text {day }}{ }^{-1}$, which is slightly lower than the growth rate of $0.16 \mathrm{~g} \mathrm{day}^{-1}$ reported by Prasad (1999), at a stocking density of $30 \mathrm{no} \mathrm{m}^{-2}$. Although stocking density of our control and IMTA pens were lower than this, the growth rate of shrimp in the present experiment was found to be low. Therefore, this could be attributed to factors that influence the growth and production of shrimp, other than stocking density, such as difference in seed quality and productivity. Khoi and Fotedar (2011) and Mai et al. (2010) reported that growth and survival of shrimp in IMTA system is similar to that in monoculture. Our present study also indicated that inclusion of extractive crop may not affect the growth and survival of shrimp.

Water quality characteristics of all the experimental farms and sites were within the admissible limits for brackishwater aquaculture. As both the pens for IMTA and control were constructed within a single pond, the differences between the treatment and control could not be evaluated. However, the soil characteristics such as organic carbon and $\mathrm{pH}$ of both pens were evaluated. Although $\mathrm{pH}$ of both control and IMTA sediments were similar (7.01 and 7.07 for control and IMTA respectively), organic carbon content of control pen was significantly higher than the IMTA pen ( $>>0.05)$. In shrimp farming, farmers are generally concerned about the accumulation of organic matter at the bottom (Peterson and Daniels, 1992). Results of the present study indicated that accumulation of organic matter is comparatively low in the IMTA ponds and it is a positive indication of health of the pond bottom.

Net income and benefit-cost ratio (BCR) of IMTA pens were found to be higher than shrimp-monoculture. Because of the logistical reasons and difficulties in obtaining sufficient replicates, particularly when experiments were carried out in farmers' pond, the economic advantage of IMTA could not be proved statistically. However, these initial experiments indicate the possible advantage of IMTA over shrimp monoculture system. In terms of profit and environmental benefits, further farming trials in the region need to be taken up with larger farming groups to propagate the benefits of IMTA as a sustainable farming system.

Most issues raised by conventional monoculture of shrimp become redundant with IMTA practices. But, to realise the potential of IMTA, it must satisfy key stakeholders, and the perceived benefits should be translated to commercial level of operation (Alexander et al., 2016). Therefore, it is imperative to up-scale the pilot level success to a commercial reality.

\section{Acknowledgements}

The study was supported by a research grant of GoI-UNDP-GEF Project on Mainstreaming Coastal Biodiversity into Production sectors in Sindhudurg Coast through Mangrove Cell, Maharashtra. We are grateful to Dr. Subir Ghosh, Project Co-coordinator of GoI-UNDPGEF Project. Thanks are due to Mr Suhel Jamadar and Ms Daya of the project for their support. We thank Dr. A. P. Dineshbabu and Dr P. K. Ashokan for their assistance during this project.

\section{References}

Abreu, M. H., Varela, D. A., Henriquez, L., Villarroel, A., Yarish, C., Sousa-Pinto, I. and Buschmann, A. H. 2009. Traditional vs. integrated multi-trophic aquaculture of Gracilaria chilensis C. J. Bird, J. McLachlan \& E. C. Oliveira: productivity and physiological performance. Aquaculture, 293(3-4): 211-220.

Alexander, K. A., Angel, D., Freeman, S., Israel, D., Johansen, J., Kletou, D., Meland, M., Pecorino, D., Rebours, C., Rousou, M. and Shorten, M. 2016. Improving sustainability 
of aquaculture in Europe: Stakeholder dialogues on Integrated Multi-trophic Aquaculture (IMTA). Environ. Sci. Policy, 55: 96-106.

Barrington, K., Ridler, N., Chopin, T., Robinson, S. and Robinson, B. 2010. Social aspects of the sustainability of integrated multi-trophic aquaculture. Aquac. Int., 18(2): 201-211.

Biswas, G.,Ananda Raja, R., De, D., Sundaray, J.K., Ghoshal,T.K., Anand, S., Kumar, S., Panigrahi, A., Thirunavukkarasu, A. R. and Ponniah, A. G. 2012. Evaluation of productions and economic returns from two brackishwater polyculture systems in tide-fed ponds. J. Appl. Ichthyol., 28(1): 116-122.

Chopin, T., Robinson, S. M. C., Troell, M., Neori, A., Buschmann, A. H. and Fang, J. 2008. Multitrophic integration for sustainable marine aquaculture. In: Jorgensen, S. E. and Fath, B. D. (Eds.), The encyclopedia of ecology, ecological engineering, vol. 3. Elsevier, Oxford, p. 2463-2475.

Eldani, A. and Primavera, J. H. 1981. Effect of different stocking combinations on growth, production and survival of milkfish (Chanos chanos Forskal) and prawn (Penaeus monodon Fabricius) in polyculture in brackishwater ponds. Aquaculture, 23(1): 59-72.

Granada, L., Sousa, N., Lopes, S. and Lemos, M. F. 2015. Is integrated multitrophic aquaculture the solution to the sectors' major challenges? - a review. Rev. Aquac. 8(3): 283-300.

Khoi, L. V. and Fotedar, R. 2011. Integration of western king prawn (Penaeus latisulcatus Kishinouye, 1896) and green seaweed (Ulva lactuca Linnaeus, 1753) in a closed recirculating aquaculture system. Aquaculture, 322: 201-220.

Luther, G. 1967. The grey mullets. Souvnir, $20^{\text {th }}$ Anniversary. Central Marine Fisheries Research Institute, Mandapam Camp, Tamil Nadu, India, p. 70-74.

Mai, H., Fotedar, R. and Fewtrell, J. 2010. Evaluation of Sargassum sp. as a nutrient-sink in an integrated seaweedprawn (ISP) culture system. Aquaculture, 310: 91-98.
MPEDA 2016. http://www.mpeda.com/HOMEPAGE.asp (Accessed: 23 April 2017).

Neori, A. and Nobre, A. M. 2012. Relationship between trophic level and economics in aquaculture. Aquac. Econ. Manage., 16(1): 40-67.

Neori, A., Shpigel, M. and Ben-Ezra, D. 2000. A sustainable integrated system for culture of fish, seaweed and abalone. Aquaculture, 186(3): 279-291.

Naylor, R. L., Goldburg, R. J., Primavera, J. H., Kautsky, N., Beveridge, M. C., Clay, J., Folke, C., Lubchenco, J., Mooney, H. and Troell, M. 2000. Effect of aquaculture on world fish supplies. Nature, 405(6790): 1017-1024.

Padmakumar, K. G., Bindu, L. and Manu, P. S. 2012 Etroplus suratensis (Bloch) state fish in Kerala. J. Bio. Sci., 37(6): 925-931.

Peterson, J. and Daniels, H. 1992. Shrimp industry perspectives on soil and sediment management. In: Wyban, J. (Ed.), Proceedings of the special session on shrimp farming. World Aquaculture Society, Baton Rouge, LA, USA, p. 182-1 86 .

Prasad, G. 1999. Growth and production of Penaeus indicus in a low saline semi-intensive culture system of Kerala. Indian J. Fish., 46(1): 25-32.

Primavera, J. H. 1997. Socio-economic impacts of shrimp culture. Aquac. Res., 28(10): 815-827.

Rana, K. J., Siriwardena, S. and Hasan, M. R. 2009. Impact of rising feed ingredient prices on aquafeeds and aquaculture production. FAO Fisheries and Aquaculture, Technical Paper, 541: 63 pp.

Reid, G. K., Cranford, P. J., Robinson, S. M. C., Filgueira, R. and Guyondet, T. 2011. Open-water integrated multi-trophic aquaculture (IMTA): modelling the shellfish component. Bull. Aquac. Ass. Canada, 109(2): 3-12.

Sadafule, N. A., Shyam, S. S. and Pandey, S. K. 2013. Economic analysis of shrimp farming in the coastal districts of Maharashtra. J. Fish. Econ. Dev., 14(1): 42-54 